\title{
DECLINE IN THE KNOWLEDGE INTENSITY OF MANUFACTURING, AND DEINDUSTRIALIZATION PROCESSES IN UKRAINE
}

\author{
Anna Voloshanska \\ Post-graduate, Ivan Franko National University of Lviv, \\ e-mail: ann.voloshanska@gmail.com, orcid.org/0000-0002-6077-5137, Ukraine
}

\begin{abstract}
The article examines the production sphere of Ukraine's economy in the context of reduction of the knowledge-intensity as a result of the processes of deindustrialization. The main reasons for the reduction of knowledge-intensity of manufacturing and decline in the economy of Ukraine are analyzed. The article also describes possible consequences of deindustrialization in the present conditions.
\end{abstract}

Keywords: deindustrialization, decline, knowledge-intensity, negative tendecies.

DOI: http://dx.doi.org/10.23856/2609

\section{Introduction}

As defined by I. Vovk (2014), deindustrialization is the process of social and economic changes, caused by decline or disappearance of an industrial activity in the region or country as a whole, in heavy industry or manufacturing in particular. Deindustrialization processes in Ukraine started in the late soviet period, what is proven by the decline in construction, depreciation of equipment and other negative tendencies of that period (Zadoya, 2012). Thus, the present condition of manufacturing, education and other spheres need to be considered for further research.

Changes in the structure of the Ukrainian economy are only formal indicators of its approach to the structure of economically developed countries and the postindustrial economy formation. In fact, since 1991 Ukraine experiencedcertain changes, primitivization of economic life, and negative deindustrialization. "The extremely rapid growth of the nonproductive sphere (services) not only is not conductive for bringing the society closer to the post-industrial one, but rather is in total contradiction and rejects it to the pre-industrial stage" (Zadoya, 2012).

It should be noted that deindustrialization in Ukraine began in the Soviet era, as evidenced by the reduction in the number of new models of machines and equipment created in the 1980s, the increase in the wear of fixed assets and other negative trends of the last Soviet decade (Zadoya, 2012).

\section{Research results}

Negative deindustrialization processes (tightly connected with the industrialization tendencies inside manufacturing (Zadoya, 2012)) were a consequence and a part of the soviet economy problems, starting in late 1960s. This and insufficient knowledge were the reasons for the inability of the majority of the country's leadershipto counteract the decline of economic growth, the increase of disproportions in wage and price policy, and the preservation of a costly system of economic management that created a shortage of goods and services. Instead of finding solutions to these problems, the government of the former Soviet Union under the guise of restructuring "state" socialism into a "democratic" carried out the 
dismantling of the socialist economic system, seeing the liberalization of the economy as an opportunity to enrich and legitimize dominant positions in a short term.

As a result, according to the member of Ukrainian academy of science A. Chukhno, «the massive dispossession of the people was carried out under the theme of market reforms. Thus, the newly created market and economy system was unable to drive Ukraine out of the crisis, on the contrary, it made the country become retarded with a resource-driven economy, instead of an industrially developed. Opposite to an increased efficiency, economy started to stagnate, production declined instead of economic development, high-technology equipment was ruined, buildings and equipment are undergoing rapid deterioration and destruction. Consequently, huge brain-drain of well-qualified workforce and scientists caused nonoperational plants and wild fields» (Chukhno, 2007).

Globalization has brought about growth in the knowledge-intensity of production across all economic activities. In a modern competitive world the development level of a country is defined by the knowledge-intensity of goods and services in the international division of labor. Developed economies' experience proves that profit a country's GDP obtains from exporting a one technological product is significantly higher that from exporting $1 \mathrm{~kg}$ steel, chemical fertilizers or wheat. Highly knowledge-intensive economy is provided by a proper skilled human capital of a country, engineers in particular. Therefore, in case of a developing country, the undeniable formula «a country deserves achievements and transformations relevant to its nation knowledge and critical skills» will always be true.

Privatization chaos in early 1990 s caused $80 \%$ of real economic potential of the Ukraine to be owned by 20 "families", while in fact state owns only $20 \%$ (Bilorus, 2000). Such an oligarch capitalism system has become a strict social obstacle for the country's economy and education development.

Latest research shows that in the education sphere Ukraine has chosen a path that is diametrically opposite to the world tendencies. There are the main negative tendencies that can be highlighted:

- decline in the quality of secondary school education, especially in the field of physics, mathematics, chemistry. Students are not willing to pursue a career in technical field;

- mostly, university students are willing to become lawyers, government servants or be employed in service sector.

Problems in the Ukrainian educational system are mainly caused by the fact that for years the science and education sphere and manufacturing were not connected. Science has not been the main factor driving economy and production growth.

This is the failure of the inadequate educated in most of the country's leadership and the failure of economic science in the USSR to counteract the economic growth decline, the increase of disproportions in wages and price policy, and the costly economic management system that created a shortage of goods and services and, as a result, dissatisfaction of people.

The degradation of high-tech industries took place in the background of the overall technological backwardness of Ukrainian production, $95 \%$ of which belonged to the third and fourth technological lines. 


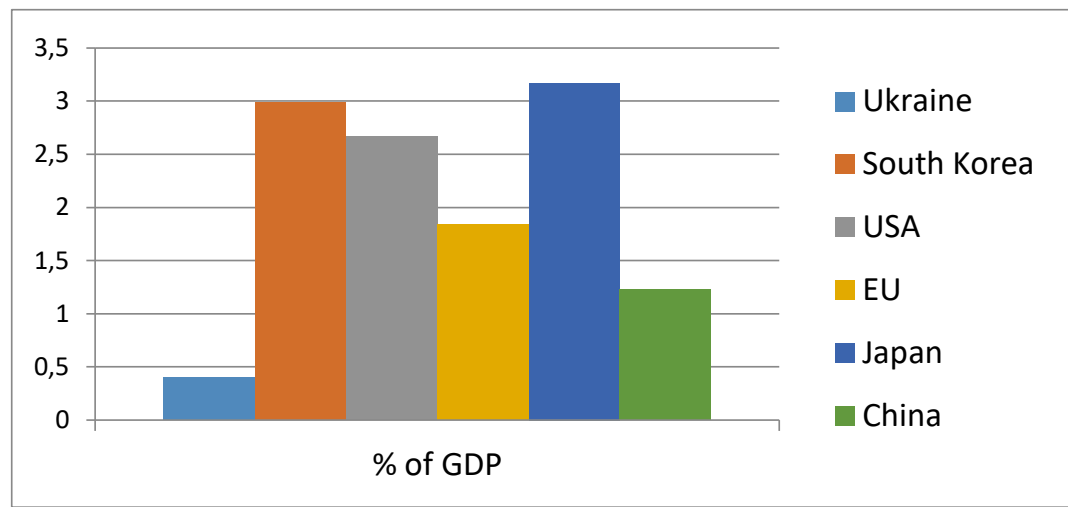

\section{Fig. 1. Comparative statistics on the financing of research activities in Ukraine and in developed countries of the world (towards European Research Area)}

Consequently, during all these years the deindustrialization processes of the Ukrainian economy become deeper. The prestige of scientific education becomes less significant, what respectively reduces the need in knowledge and technology skills. Such a deformation of the value system has led to significant qualitative losses in the field of productive human capital preparation, humiliation and displacement from the country's bestcarriers of engineering knowledge. The current recommendations of the Ministry of Education and Science of Ukraine will lead to an increase in disproportions between the representatives of the production and services sectors and will contribute to the further decline of the country.

According to a recent opinion poll, 5-6\% of economically active population is ready to go abroad for a temporary employment. According to the Ukrainian-Polish sociological research, more than $60 \%$ of illegal work migrants are not willing to come back to Ukraine. The next negative tendency is even more shocking - around $80 \%$ of Ukrainian students are willing to work abroad if they have such an opportunity.

Slack demand for scientific potential has become one of the heaviest consequences of Ukraine's deindustrialization. It caused an intensive brain-drain. According to the Presidium of the National Academy of Sciences of Ukraine, in 1994-2001 3,838 scientists went from their research institutions to foreign countries, including 842 post-doctoral research assistants and 2358 doctors of sciences (Ponomarenko, 2008). The number of research scientists in the country for the period 1990-2015 has decreased by 4.5 times (Statistical Yearbook, 2016).

«It's a shame to realize that Ukraineis now at the level of third countries for scientific production. Almost all financial flows, including the ones from the state budget, are aimed not to contribute to the creation of a technological base, that can only be provided by scientific growth, but to exploit, convey the existing, which can not provide anything other than obtaining scientific "raw materials" - primary data, preconditions, hypotheses» (Zholobak, 2008).

\section{Conclusions and suggestions}

In the present conditions, the education system of Ukraine needs to be revised. It concerns the quality of higher education, science instituted, and international competitiveness of Ukrainian education system. High level of scientific preparation of human capital will help 
to reduce the brain-drain from the country, thus, to create new solutions for the intensification of a technology component in the economy.

With such a further attitude a very small intellectual human capital will continue to become even less numerous. Ukraine will lose the ability not only to obtain new technologies and inventions, but also to exchange the accumulated knowledge with other countries, transfer new technologies, and expect economic development.

Practice has shown that the growth and complication of needs caused the emergence of new types of services, what means a special, individualized approach to meeting the needs of individual customers, the tendency to more and more comprehensive implementation of the product requirements of a particular consumer to the amount of benefits and positive effects (Chase, 1999).

Deindustrialization is seen as a trend that causes anxiety and need for regulations in the economyin order to support the development of knowledge-intensive industries that are linked to other sectors of the economy and are an important source of innovation and economic wellbeing.

\section{References}

Bilorus, O., Pavlovskiy, M. (2000). Pryide sudnyi den na kryminalnyh oligarhiv. Golos Ukrainy, No. 18. [in Ukrainian].

Chase, R. B., Garvin, D. A. (1999). The Service Factory. Harvard Business Review, 4, 61 69. [in English].

Chukhno, A. (2007). Management mechanism and the ways of its improvement at present stage. Economy of Ukraine, 3. 60-67. [in Ukrainian].

European Research Area. Science, Technology and Innovation. Key Figures 2007.

More than $80 \%$ of university graduates want to work abroad. (2018). [Electronic resource]. Retrieved from http://finance.bigmir.net/career/13477-Bolee-80-vypusknikov-vuzovhotjatrabotat-za-granicej. [in Ukrainian].

Ponomarenko, V. (2008). Trudovaia emihratsiia v razvitiye nauki v Ukraine. Propaganda, 1(3), 12-14. [in Russian].

Russo, J., Linkon, S. L. (2002). The Social Costs of Deindustrialization. [Electronic resource]. Retrieved from http://cwcs.ysu.edu/resources/CWCS-publications/ social-costs-ofdeindustrialization/.[in English].

Statystychnyi shchorichnyk Ukrainy za 2015 rik. (2016). Kiyv: TOV «Avhust Treid».[in Ukrainian].

Towards a European research area - Science, technology and innovation. (2007). Key figures 2007. [Electronic resource]. Retrieved from http://aei.pitt.edu/46027/. [in English].

Vovk, I. V. (2014). Poniattia "reindustrializatsia” v suspilniy georgafii. Naukoviy visnyk Chernivetskoho ukiversytetu. Chernivtsi : Chernivetskiy natsionalnyi universytet, V. 696, 7680. [in Ukrainian].

Zadoia, A. A. (2012). Deindustrializatsiia v Ukraine: “Dvadtsat let spustia”. Akademichnyi ohliad, 1 (36), 26-35. [in Russian].

Zholobak, N. (2008). Intehratsia v myrovoe nauchnoe soobshchestvo ili «vikachka mozghov». Propaganda, 1 (3), 4-5. [in Russian]. 